\title{
Ontogeny of Calcium Transport By Intestinal Golgi in Spontaneously Hypertensive Rats and Genetically Matched WKY Rats
}

\author{
HARUMICHI SHIBATA AND FAYEZ K. GHISHAN \\ Department of Pediatrics and Molecular Physiology and Biophysics, Division of Gastroenterology, \\ Vanderbilt University, Nashville, Tennessee 37232
}

\begin{abstract}
Our studies were designed to characterize calcium transport by intestinal Golgi vesicles in spontaneously hypertensive rats (SHR) and their genetically matched control, Wistar-Kyoto rats (WKY). The biochemical purity of the intestinal Golgi in SHR and WKY was validated by marker enzyme studies. Calcium uptake by Golgi vesicles represented transport into the intravesicular space as evidenced by temperature dependency and by calcium ionophore A23187-induced calcium efflux experiments. ATP-driven calcium uptake was stimulated severalfold compared with uptake in the absence of ATP and adenylyl- $(\beta-\gamma$-methylendiphosphate)(nonhydrolyzable ATP) in both SHR and WKY. ATP-dependent calcium uptake was significantly higher in WKY compared with SHR at early times points, $15 \mathrm{~s}-5 \mathrm{~min}(p<0.05-0.01)$. The initial rate of calcium uptake was linear up to $60 \mathrm{~s}$. Kinetic parameters of calcium uptake at free calcium concentrations of 0.1 to $2.0 \mu \mathrm{M}$ showed a $V_{\max }$ of $1.64 \pm 0.06$ and $1.2 \pm 0.06 \mathrm{nmol} \cdot \mathrm{mg}$ protein ${ }^{-1} \cdot 15 \mathrm{~s}^{-1}$ in WKY and SHR, respectively $(p<0.01)$, and the $K m$ values were $0.17 \pm 0.03$ and $0.16 \pm 0.04 \mu \mathrm{M}$, respectively. Kinetic analysis of ATP-dependent calcium uptake in 3-wk-old rats showed a $V_{\max }$ of $0.07 \pm 0.005$ and $0.36 \pm 0.05 \mathrm{nmol} /$ mg protein ${ }^{-1} \cdot 15 \mathrm{~s}^{-1}(p<0.01)$ and a $\mathrm{Km}$ of $0.26 \pm 0.08$ and $0.4 \pm 0.2 \mu \mathrm{M}$ in SHR and WKY, respectively. These results suggest that intestinal Golgi vesicles in SHR and WKY demonstrate an ATP-driven calcium uptake. This ATP-dependent process is significantly decreased in the weanling and adult SHR compared with WKY. Such an abnormality in intracellular calcium regulation may have a role in the development of hypertension. (Pediatr Res 28: 591-594, 1990)
\end{abstract}

\section{Abbreviations}

AMP-PCP, adenylyl- $(\beta$ - $\gamma$-methylendiphosphate $)$ CTP, cytosine triphosphate

SHR, spontaneously hypertensive rat WKY, Wistar-Kyoto rat

Epidemiologic studies suggested an inverse relationship between blood pressure and dietary calcium intake (1-5). Oral calcium supplementation in humans resulted in reduction in blood pressure (6). Furthermore, low serum level of ionized calcium has been described in humans with essential hyperten-

Received April 11, 1990; accepted July 26, 1990.

Correspondence: Fayez K. Ghishan, M.D., Department of Pediatrics, Vanderbilt University, Medical Center North D-4130, 21 st and Garland, Nashville, Tennessee 37232.

Supported by Grant no. NIH HL37961. sion (7). These studies suggest an alteration of calcium homeostasis in humans with essential hypertension.

The SHR is the most widely used animal model of human essential hypertension (8). Calcium metabolism in SHR has been shown by several studies to be abnormal. These abnormalities include reduced serum ionized calcium, increased serum parathormone levels, hypercalciuria, and abnormal vitamin D metabolism (9-16). Studies on calcium transport using in vivo and in vitro techniques, in general, have shown decreased calcium uptake by the small intestine of the SHR when compared with WKY $(12,15,16,17,18)$. Calcium transport across the enterocyte, however, represents three steps that include: entry across brush border membrane, cytosolic movement, and exit of the basolateral membrane. To our knowledge, there are no studies to address the cytosolic movement of calcium within the enterocytes. Because the Golgi apparatus plays a major role in intracellular calcium handling $(19,20)$ and abnormalities in intracellular calcium handling have been reported in tissues of SHR (21), we postulated that calcium uptake by Golgi apparatus might be abnormal.

Therefore, our studies were designed to characterize calcium transport by intestinal Golgi of the SHR and their genetically matched control, WKY. Furthermore, calcium uptake was studied before (3-wk-old rats) and after development of hypertensive state (12-wk-old).

\section{MATERIALS AND METHODS}

Animals and materials. Both SHR and WKY were obtained from Taconic Farms (Germantown, NY). Adult rats (12-14 wk old) and weanling rats $(21 \pm 1 \mathrm{~d}$ old $)$ were used to prepare the intestinal Golgi vesicles. Adult and weanling rats were fed a regular diet that contained $1.2 \%$ calcium, 0.8 phosphate, and $1700 \mathrm{U} / 100 \mathrm{~g}$ of ergocalciferol (Teklad Diets, Madison, WI).

${ }^{45} \mathrm{Ca}(0.37-1.5 \mathrm{GBq} / \mathrm{mg})$ was obtained from New England Nuclear Corporation (Boston, MA). Enzymes and substrates were obtained from Sigma Chemical Corporation (St. Louis, $\mathrm{MO})$. Cellulose nitrate filters, $0.45-\mu \mathrm{m}$ pore size were obtained from Sartorius Filters, Inc. (Hayward, CA). All other chemicals were of the highest purity available.

Preparation of Golgi vesicles. The intestinal Golgi vesicles were prepared from the jejunum of four adult or 12 weanling rats. Rats were killed by cervical dislocation. The jejunal region extended from the ligament of Treitz to 30 and $50 \mathrm{~cm}$ aborally in weanling and adult rats, respectively. The intestinal segments were removed, flushed with cold normal saline and then filled with warmed buffer solutions $\left(37^{\circ} \mathrm{C}\right)$ containing $1.5 \mathrm{mM} \mathrm{KCl}$, $96 \mathrm{mM} \mathrm{NaCl}, 8 \mathrm{mM} \mathrm{KH} \mathrm{PO}_{4}, 5.6 \mathrm{mM} \mathrm{Na}_{2} \mathrm{HPO}_{4}, 27 \mathrm{mM} \mathrm{Na}_{3}$ citrate, and $2 \mathrm{mM}$ DTT ( $\mathrm{pH} 7.2$ ). The segments were clamped and incubated in the same buffer without DTT (this buffer will be called citrate buffer from now on) for $15 \mathrm{~min}$ in a shaking water bath at $37^{\circ} \mathrm{C}$. The clamps were then removed and the 
contents were emptied. The segments were filled with cold citrate buffer and were clamped and palpitated for $5 \mathrm{~min}$ on a cold plate to release epithelial cells. The clamp was then removed and the epithelial cells were emptied. The enterocytes were collected at $500 \times g$ for $10 \mathrm{~min}$. The enterocytes were then homogenized in $42.5 \mathrm{mM} \mathrm{Na} 2 \mathrm{HPO}_{4}, 20 \mathrm{mM} \mathrm{KH} \mathrm{PO}_{4}, 250 \mathrm{mM}$ sucrose, $1 \%$ dextran, $10 \mathrm{mM} \mathrm{MgCl}$ ( $\mathrm{pH}$ 7.2) with three strokes in glassTeflon homogenizer. The cells were then further fractionated in a Parr Bomb (Parr Instrument Co., Moline, IL) at 1000 pounds per square inch for $60 \mathrm{~min}$. The slowly discharged cell fractions were then layered on an unbuffered aqueous $1.25 \mathrm{M}$ sucrose pad (22) and were centrifuged in an SW28 rotor nonstop in the following manner: at $3300 \times g$ for $10 \mathrm{~min}, 13200 \times g$ for 10 $\min$, and $82600 \times g$ for $45 \mathrm{~min}$.

The Golgi-rich fraction appeared as a white band at the interface. This band was then diluted in $260 \mathrm{mM}$ sucrose and $5 \mathrm{mM}$ imidazole ( $\mathrm{pH} 7.2$ ) and the Golgi was collected at $60000 \times g$ for $30 \mathrm{~min}$.

Marker enzyme enrichment. Galactosyl transferase, a marker of Golgi, was measured as described by Moore et al. (22) and

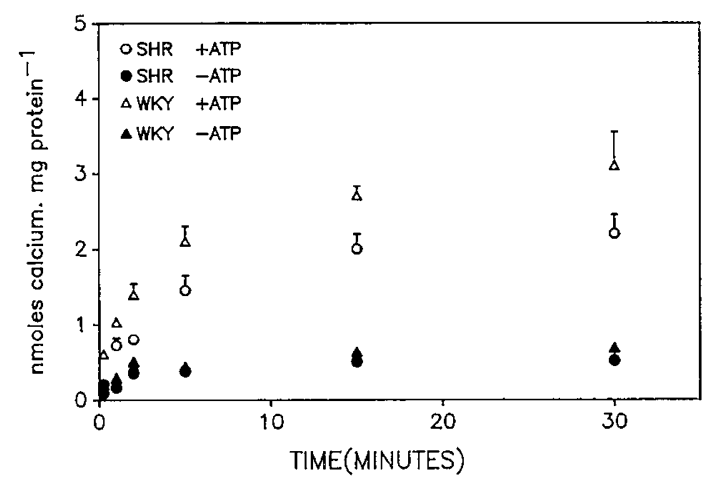

Fig. 1. Calcium uptake with time in adult SHR and WKY in the presence and absence of ATP. Golgi vesicles were prepared in $260 \mathrm{mM}$ sucrose, $5 \mathrm{mM}$ imidazole, $\mathrm{pH}$ 7.2. Incubation was started by the addition of Golgi vesicles to a media containing, in final concentration, either 130 $\mathrm{mM} \mathrm{KCl}, 1.3 \mathrm{mM}$ EGTA, $3 \mathrm{mM}$ MgATP, $1 \mathrm{mM} \mathrm{MgCl}_{2}, 27.5 \mathrm{mM}$ imidazole, $0.11 \mathrm{mM}$ dinitrophenol, $1.1 \mathrm{mM} \mathrm{NaN}_{3}$, pH 7.2, $1 \mu \mathrm{M}$ calcium, and tracer ${ }^{45} \mathrm{Ca}$ or similar solution except for the omission of ATP. Reaction was stopped at $15 \mathrm{~s}, 30 \mathrm{~s}$, and 1, 2, 5, 15, and $30 \mathrm{~min}$. Values are mean $\pm \mathrm{SEM}$ of three separate experiments on different membrane preparations run in triplicate.

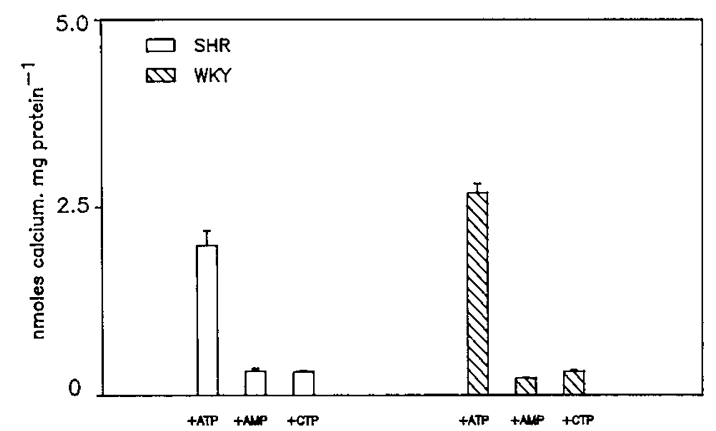

Fig. 2. Effect of AMP-PCP (a nonhydrolyzable ATP) and CTP on calcium uptake by Golgi vesicles of adult SHR and WKY. Golgi vesicles were prepared in $260 \mathrm{mM}$ sucrose, $5 \mathrm{mM}$ imidazole $\mathrm{pH}$ 7.2. Incubation was started by the addition of Golgi vesicles to a media containing, in final concentration, $130 \mathrm{mM} \mathrm{KCl}, 1.3 \mathrm{mM}$ EGTA, $1 \mathrm{mM} \mathrm{MgCl} 2,27.5$ $\mathrm{mM}$ imidazole, $0.11 \mathrm{mM}$ dinitrophenol, $1.1 \mathrm{mM} \mathrm{NaN}_{3} \mathrm{pH} 7.2,1 \mu \mathrm{M}$ $\mathrm{CaCl}_{2}$, tracer ${ }^{45} \mathrm{Ca}$, and either $3 \mathrm{mM} \mathrm{MgATP}$, AMP-PCP, or CTP. Reaction was stopped at 15 min. Values are mean \pm SEM of three separate experiments on different membrane preparations. Mean values with ATP are significantly greater compared with corresponding mean values with AMP-PCP or CTP in both SHR and WKY rats $(p<0.001)$.

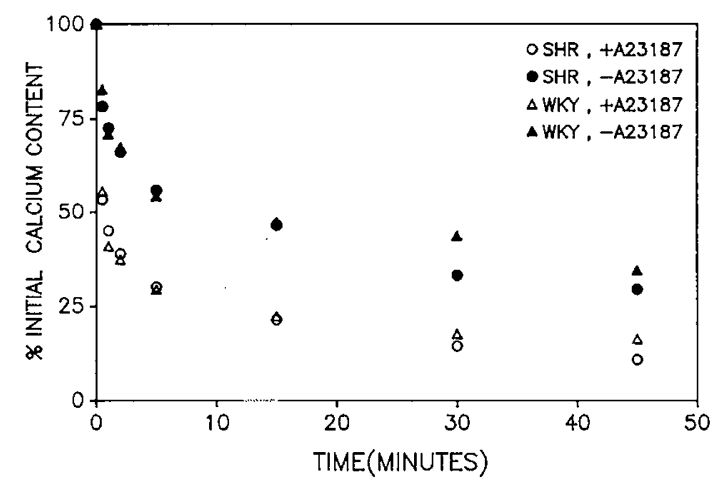

Fig. 3. Effects of calcium ionophore A23187 on calcium efflux from Golgi vesicles in SHR and WKY. Golgi vesicles were prepared in 260 $\mathrm{mM}$ sucrose and $5 \mathrm{mM}$ imidazole $\mathrm{pH}$ 7.2. Vesicles were loaded with 1 $\mu \mathrm{M} \mathrm{CaCl}_{2}$ and ${ }^{45} \mathrm{Ca}$ in a manner similar to that described for calcium uptake studies with ATP. Calcium efflux was initiated by diluting loaded vesicles in a similar incubation with $10 \mu \mathrm{g} / \mathrm{mg}$ protein of A23187. Calcium efflux was determined with time. Values are expressed as percent of initial values at zero time points. Each point represents mean \pm SEM of three separate experiments run in triplicate.

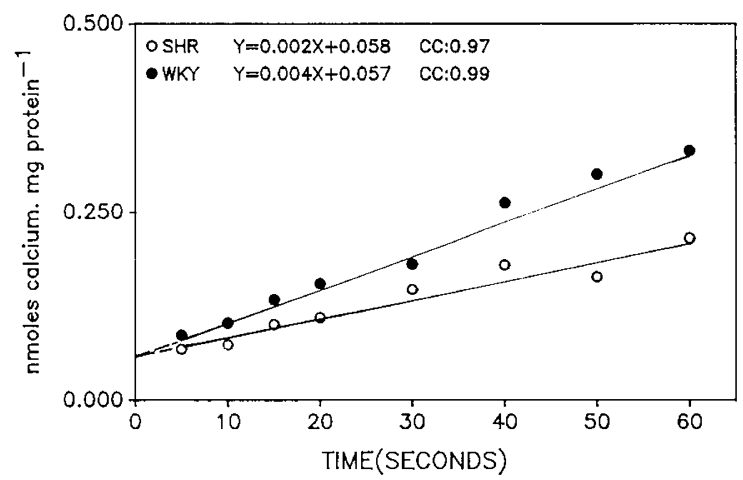

Fig. 4. Initial rate of calcium uptake in weanling SHR and WKY. Golgi vesicles were prepared in $260 \mathrm{mM}$ sucrose and $5 \mathrm{mM}$ imidazole $\mathrm{pH}$ 7.2. Incubation was started by the addition of Golgi vesicles to a media containing, in final concentration, $130 \mathrm{mM} \mathrm{KCl}, 1.3 \mathrm{mM}$ EGTA, $1 \mathrm{mM} \mathrm{MgCl} 2,27.5 \mathrm{mM}$ imidazole, $0.11 \mathrm{mM}$ dinitrophenol, $1.1 \mathrm{mM}$ $\mathrm{NaN}_{3}, \mathrm{pH} 7.2,3 \mathrm{mM} \mathrm{MgATP}, 1 \mu \mathrm{M} \mathrm{CaCl}_{2}$, and tracer ${ }^{45} \mathrm{Ca}$. Calcium uptake was linear up to $60 \mathrm{~s}$ in SHR and WKY. Values are mean \pm SEM and represent three separate experiments run in triplicate.

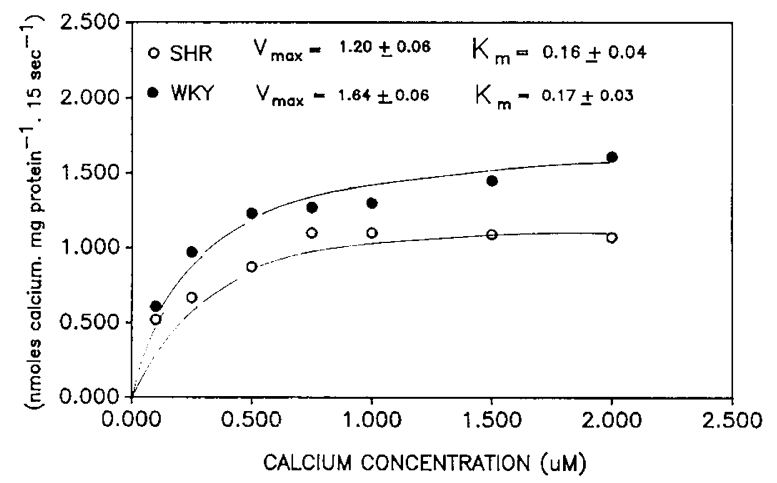

Fig. 5. Kinetics of calcium uptake in adult SHR and WKY. Intestinal Golgi vesicles were prepared in $260 \mathrm{mM}$ sucrose and $5 \mathrm{mM}$ imidazole buffer $\mathrm{pH}$ 7.2. ATP-dependent calcium uptake was determined at $15 \mathrm{~s}$ with a range of calcium concentrations in the media from $0.1-2.0 \mu \mathrm{M}$. Kinetic parameters were obtained using a computerized model of the Michaelis-Menten kinetics. The $\mathrm{V}_{\max }$ value in WKY was significantly greater compared with corresponding mean values in $\operatorname{SHR}(p<0.01)$. 


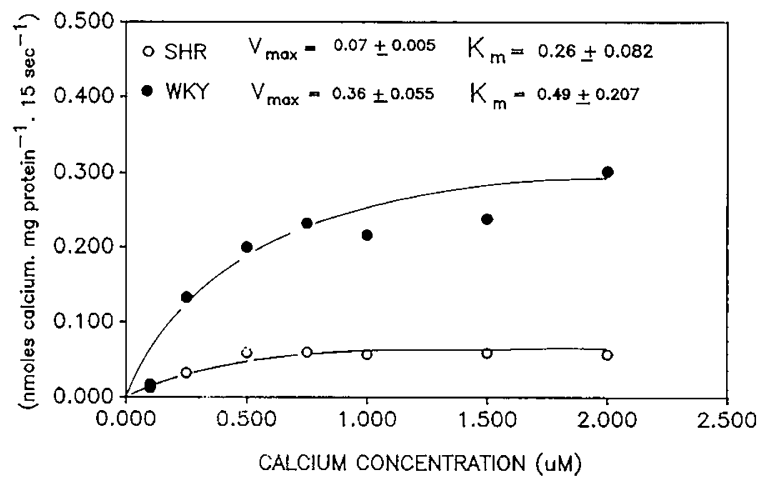

Fig. 6. Kinetics of calcium uptake in weanling (3-wk-old) SHR and WKY. Golgi vesicles were prepared in $260 \mathrm{mM}$ sucrose and $5 \mathrm{mM}$ imidazole buffer $\mathrm{pH}$ 7.2. ATP-dependent calcium uptake was determined at $15 \mathrm{~s}$ with a range of calcium concentrations in the media from 0.1 to $2.0 \mu \mathrm{M}$. Kinetic parameters were obtained using a computerized model of the Michaelis-Menten kinetics. The $\mathrm{V}_{\max }$ value in weanling WKY was significantly greater compared with the corresponding mean value in SHR $(p<0.001)$.

cytochrome $\mathrm{C}$ reductase and oxidase markers of endoplasmic reticulum and mitochondria, respectively, were measured as described by Beaufay et al. (23). $\mathrm{Na}^{+} / \mathrm{K}^{+}$-ATPase, a marker for basolateral membrane, was measured by the method of Scharschmidt et al. (24). Protein was measured by the method of Lowry et al. (25) using BSA as the standard.

Transport measurements. Uptake of calcium was measured by a rapid filtration technique. In brief, Golgi vesicles were incubated in the transport buffer $(260 \mathrm{mM}$ sucrose, $5 \mathrm{mM}$ imidazole, $\mathrm{pH}$ 7.2). The uptake study was initiated by the addition of 20 $\mu \mathrm{L}$ of vesicle to $80 \mu \mathrm{L}$ of labeled incubation media. The final concentrations of constituents were as follows: $130 \mathrm{mM} \mathrm{KCl}, 1.3$ $\mathrm{mM}$ EGTA, $1 \mathrm{mM} \mathrm{MgCl} 2,27.5 \mathrm{mM}$ imidazole, $0.11 \mathrm{mM}$ dinitrophenol, $1.1 \mathrm{mM} \mathrm{NaN}_{3}$, and $3 \mathrm{mM} \mathrm{MgATP}$ or $3 \mathrm{mM}$ AMP-PCP. Micromolar concentration of free calcium was obtained by Ca-EGTA buffering system as detailed by Pershadsingh and McDonald (26). All experiments were performed at $25^{\circ} \mathrm{C}$ unless otherwise indicated. The reaction was stopped by addition of $1 \mathrm{~mL}$ of cold stop solution containing $100 \mathrm{mM}$ mannitol, 100 $\mathrm{mM} \mathrm{MgCl}$, and $20 \mathrm{mM} N$-2-hydroxyethylpiperazine- $N^{\prime}$-2-ethanesulfonic acid/Tris ( $\mathrm{pH}$ 7.2). The vesicles were filtered immediately over a cellulose nitrate filter under suction and washed with $5 \mathrm{~mL}$ of stop solution. The amount of radioactive substrate remaining on the filter was determined in a liquid scintillation counter (Beckman Instruments, Palo Alto, CA), using Scinti Verse II (Fisher Scientific, Norcross, GA) as a liquid scintillant.

Statistical analysis. All data were statistically analyzed as mean \pm SEM and the significance of difference was determined using unpaired $t$ test. Each experiment was repeated three times and was run in triplicate. $\mathrm{Km}$ and $\mathrm{V}_{\max }$ were determined according to a computer model for estimation of Michaelis-Menten kinetic parameter (27).

\section{RESULTS}

Purity of Golgi vesicles. The activities of $\mathrm{Na}^{+} / \mathrm{K}^{+}$-ATPase, cytochrome $\mathrm{C}$ oxidase, and reductase markers of basolateral membrane, mitochondria, and endoplasmic reticulum, respectively, were impoverished at $0.4,0.5$, and 0.5 times, respectively. The activity of galactosyl transferase, a marker of Golgi, was enriched 30 and 32 times, respectively, in adult WKY and SHR. A similar activity was obtained for both 3-wk-old WKY and SHR.

ATP-driven calcium uptake with time. As seen in Figure 1 at each time point studied, $\mathrm{Ca}^{++}$uptake in the presence of ATP was stimulated several-fold compared with the no ATP condition in both SHR and WKY. Calcium uptake with ATP was higher in WKY compared with SHR values $(p<0.05-0.01)$ at $15 \mathrm{~s}$ to 5 min. Uptake values in the absence of ATP were similar.

Effect of nonhydrolyzable ATP (AMP-PCP) and CTP. To determine the requirement for the hydrolysis of the $\beta$-phosphodiester bond for the stimulatory effect of ATP, we investigated the effect of $5 \mathrm{mM}$ of a nonhydrolyzable ATP analogue, AMPPCP, on calcium uptake. The specificity of the adenosine base was tested by the addition of $5 \mathrm{mM} \mathrm{CTP}$ to the incubation media instead of ATP. Both AMP-PCP and CTP decreased calcium uptake by more than $80 \%$ in SHR and WKY (Fig. 2).

Effect of temperature on $\mathrm{Ca}^{++}$uptake. Calcium uptake with time was determined at 25 and $0^{\circ} \mathrm{C}$. Calcium uptake was significantly decreased at $0^{\circ} \mathrm{C}$ compared with $25^{\circ} \mathrm{C}$ in both SHR and WKY, respectively. Calicum uptake values at $0^{\circ} \mathrm{C}$ at $30 \mathrm{~min}$ in SHR and WKY were $0.12 \pm 0.02$ and $0.13 \pm 0.02 \mathrm{nmol} / \mathrm{mg}$ protein compared with control values at $25^{\circ} \mathrm{C}$ of $2.1 \pm 0.2$ and $3.2 \pm 0.3 \mathrm{nmol} / \mathrm{mg}$ protein, respectively $(p<0.001)$.

Effect of calcium ionophore A23187 on calcium efflux. The effect of calcium ionophore A23187 at $10 \mu \mathrm{g} / \mathrm{mg}$ protein on calcium efflux from calcium-loaded Golgi vesicles was determined. As seen in Figure 3, calcium efflux in the presence of A23187 occurred rapidly compared with efflux in the absence of A23187 in both SHR and WKY, respectively, suggesting that calcium was present in the intravesicular space.

Effect of $50 \mu M$ sodium vanadate on calcium uptake. Sodium vanadate inhibited calcium uptake in Golgi vesicles of SHR and WKY by more than $80 \%$ at $15 \min (p<0.001)$.

Initial rate uptake. Figure 4 depicts the initial rate of calcium uptake in SHR and WKY. At each time point studied, calcium uptake was significantly decreased in weanling SHR compared with WKY $(p<0.05-0.01)$. Calcium uptake was linear up to $60 \mathrm{~s}$ in SHR $(\mathrm{y}=0.002 \mathrm{x}+0.058, r=0.99)$ and WKY $(\mathrm{y}=$ $0.004 x+0.057, r=0.99)$. The slope of the line in WKY was significantly different compared with its corresponding value in SHR $(p<0.05)$. The intercept representing a minimal binding component was similar in both membranes of WKY and SHR (0.058 and 0.057). A similar relationship occurred in adult SHR and WKY with linear regressions of $\mathrm{y}=0.02 \mathrm{x}+0.04, r=0.98$ and $\mathrm{y}=0.032 \mathrm{x}+0.05, r=0.98$, respectively. The slopes between adult SHR and WKY are significantly different $(p<0.05)$.

Kinetics of calcium uptake. Figure 5 shows the kinetic parameter of calcium uptake in adult SHR and WKY. Calcium uptake was determined at free concentration of $0.1-2.0 \mu \mathrm{M}$ in the presence and absence of ATP. Km and $V_{\max }$ were calculated using a computerized model of Michaelis-Menten kinetic (26). Values used in the kinetic represents uptake values in the presence of ATP minus those in the absence of ATP. $V_{\max }$ values were $1.64 \pm 0.06$ and $1.20 \pm 0.06 \mathrm{nmol} \cdot \mathrm{mg} \mathrm{protein}^{-1} \cdot 15 \mathrm{~s}^{-1}$ for adult WKY and SHR, respectively $(p<0.01)$, and $\mathrm{Km}$ values were $0.17 \pm 0.03$ and $0.16 \pm 0.04 \mu \mathrm{M}$ for adult WKY and SHR, respectively. As seen in Figure $6, V_{\max }$ values for weanling WKY and SHR were $0.36 \pm 0.05$ and $0.07 \pm 0.005 \mathrm{nmol} \cdot \mathrm{mg}_{\text {protein }}{ }^{-1}$. $15 \mathrm{~s}^{-1}(p<0.01)$, and $\mathrm{Km}$ values were $0.26 \pm 0.08$ and $0.49 \pm$ $0.2 \mu \mathrm{M}$, respectively.

\section{DISCUSSION}

Our studies characterize calcium uptake by Golgi apparatus in SHR and their normotensive control, WKY. The biochemical and functional purity of the Golgi vesicles prepared from fresh enterocytes was validated by marker enzyme studies. Furthermore, we used sodium azide and dinitrophenol in our preparation to inhibit any contaminating mitochondrial preparation. These validation studies are similar to our previously published data on Golgi vesicles of Sprague-Dawley rats (19).

Calcium sequestration within the cytosol occurs by equilibrium binding to high affinity sites on cytosolic membrane or soluble protein $(28,29)$ or by active transport to subcellular organelles $(19,30,31)$. Warner and Coleman (20) suggested a role for Golgi in intracellular calcium movement by the dem- 
onstration of electron-dense intracellular calcium deposits in the area of Golgi of the small intestine of vitamin D-deficient rats. Furthermore, Maclaughlin et al. (32) have shown that Golgi vesicles bind calcium avidly and the binding decreases with vitamin $\mathrm{D}$ deficiency.

Our studies demonstrate that the time course of calcium uptake in the presence of ATP was stimulated several-fold compared with that in the absence of ATP in SHR and WKY. These results are similar to those reported for ATP-dependent calcium uptake by the Golgi in Sprague-Dawley rats (19). The requirement for the hydrolysis of ATP was shown by the lack of stimulation of calcium uptake in the presence of AMP-PCP, a nonhydrolyzable ATP analogue. The specificity of the adenosine base was shown by the lack of stimulation by CTP.

The initial rate of calcium uptake was higher in adult and weanling WKY compared with SHR $(p<0.05-0.01)$. Kinetic parameter showed that this increase is secondary to a greater $\mathrm{V}_{\max }$ in WKY compared with SHR.

To define whether calcium uptake represents binding or transport into the vesicular space, calcium uptake was determined at 25 and $0^{\circ} \mathrm{C}$ in WKY and SHR. The marked decrease in calcium transport at $0^{\circ} \mathrm{C}$ compared with $25^{\circ} \mathrm{C}$ is consistent with the concept that a major component of calcium uptake represents transport into the intravesicular space rather than binding in both WKY and SHR. The second experiment was a calcium efflux study using calcium ionophore A23187. As seen in Figure 3 , calcium efflux in the presence of ionophore A23187 occurred more rapidly from the vesicles in both WKY and SHR compared with efflux with no ionophore present. The third experiment tested the inhibitory effect of sodium vanadate on ATP-dependent calcium uptake. Vanadate inhibited calcium uptake by more than $80 \%$. These three studies, coupled with the small value for the intercept in the initial rate studies, suggest that calcium uptake by Golgi vesicles represents transport into the intravesicular space driven by the hydrolysis of ATP rather than binding.

The decrease in ATP-dependent calcium uptake in SHR was also present in the prehypertensive weanling SHR compared with WKY. This observation suggests that the abnormalities in intracellular calcium handling are genetically determined and are not secondary phenomena in response to the hypertensive state. This decrease is not secondary to the decrease in vitamin $\mathrm{D}$ level because our recent data showed that serum levels of $25(\mathrm{OH})_{2}$ vitamin $\mathrm{D}$ were similar in the SHR and WKY (33). Decreased uptake of calcium by Golgi vesicles may lead to an increase in intracellular calcium concentration with increased availability of calcium to contractile proteins. Such an increase in intracellular calcium concentration has been shown to be present in various tissues of SHR and humans with hypertension $(34,35)$. In summary, our studies clearly demonstrate abnormalities in intracellular calcium handling by subcellular organelles of the enterocytes. These abnormalities are present before the appearance of hypertension and may represent a generalized phenomena in tissues of the SHR that may have a role in the development of hypertension.

\section{REFERENCES}

1. McCarron DA, Morris CD, Cole C 1982 Dietary calcium in human hypertension. Science 217:267-269

2. McCarron DA, Morris CD, Henry JH, Stanton JL 1984 Blood pressure and nutrient intake in the United States. Science 224:1392-1397

3. Harlan SR, Hall AL, Schmouder RL, Landis JR, Thompson FE, Larkin FA 1984 Blood pressure and nutrition in adults. Am J Epidemiol 120:17-28

4. Harlan WR, Hall AL, Schmouder RL, Landis JR, Larkin FA, Thompson FE 1984 High blood pressure in older Americans: the first national health and nutrition examination survey. Hypertension 6:802-809

5. Joffres MR, Reed DM, Yano K 1987 Relationship of magnesium intake and other dietary factors to blood pressure: the Honolulu heart study. Am J Clin Nutr 45:469-475

6. Belizan JM, Villar J, Pineda O, Gonzalez A, Saing E, Garrera G, Sibrian R 1983 Reduction of blood pressure with calcium supplementation in young adults. JAMA 249(8):1 161-1165

7. McCarron DA 1982 Low serum concentrations of ionized calcium in patients with hypertension. N Engl J Med 307:226-228

8. Okamoto K, Aoki K 1963 Development of a strain of spontaneously hypertensive rats. Jpn Circ J 27:282-293

9. McCarron DA, Yung NN, Ugoretz BA, Krutzik S 1981 Disturbances of calcium metabolism in the spontaneously hypertensive rat. Hypertension 43:I162-I167

10. Wright GL, Toraason M, Barke J, Crouse W 1980 The concentrations of ionic and total calcium in plasma of the spontaneously hypertensive rat. Can $\mathbf{J}$ Physiol Pharmacol 58:I484-I499

11. Wright GL, Rankin GO 1982 Concentrations of ionic and total calcium in plasma of four models of hypertension. Am J Physiol 243:H365-H370

12. Stern N, Lee DBN, Silis V, Beck FWJ, Deftos L, Manolagas SC, Somers JR 1984 Effects of high calcium intake on blood pressure and calcium metabolism in young SHR. Hypertension 6:639-646

13. Ayachi $S 1979$ Increased dietary calcium lowers blood pressure in the spontaneously hypertensive rat. Metabolism 28:1234-1238

14. Lau K, Zikos D, Spirnak JS, Eby B 1984 Evidence for an intestinal mechanism in hypercalciuria of spontaneously hypertensive rats. Am J Physiol 247:E625-E633

15. Schedl HP, Miller DL, Pope JM, Horst RL, Wilson HD 1984 Calcium and sodium transport and vitamin D metabolism in the spontaneously hypertensive rat. J Clin Invest 743:980-986

16. Kurtz TW, Portale AA, Morris RC 1986 Evidence for a difference in vitamin $\mathrm{D}$ metabolism between spontaneously hypertensive and Wistar-Kyoto rats. Hypertension 8:1015-1020

17. McCarron DA, Lucas PA, Schneidman RJ, LaCour B, Drueke T 1985 Blood pressure development of the spontaneously hypertensive rat after concurrent manipulation of $\mathrm{Ca}^{++}$and $\mathrm{Na}^{+}$: relation to intestinal fluxes. J Clin Invest $76: 1147-1154$

18. Bindels RJM, Van den Brock LAM, Jougen MJM, Hackeng WHL, Lourik CWGM, Van Os CH 1987 Increased plasma calcitonin levels in young spontaneously hypertensive rats: role in disturbed phosphate homeostasis. Pflugers Arch 408:395-400

19. Arab N, Ghishan FK 1989 Vitamin D regulated ATP driven $\left(\mathrm{Ca}^{++}\right)$uptake by intestinal Golgi vesicles during maturation. Pediatr Res 26:58-62

20. Warner RR, Coleman JR 1975 Electron probe analysis of calcium transport by small intestine. $\mathrm{J}$ Cell Biol 64:54-74

21. Swift L, Soule PD, Gray ME, LeQuire VS 1984 Intestinal lipoprotein synthesis: comparison of nascent Golgi lipoproteins from chow-fed and hypercholesterolemic rats. J Lipid Res 25:1-13

22. Moore DJ, Merlin LM, Keenan TW 1969 Localization of glycosyl transferase activities in a Golgi apparatus-rich fraction isolated from rat liver. Biochem Biophys Res Commun 37:813-819

23. Beaufay H, Costesce AA, Feytmans F, Wibo M, Robbi M, Berthet J 1974 Analytical study of microsomes and isolated subcellular membranes from rat liver. J Cell Biol 6:188-200

24. Scharschmidt BF, Keefe ED, Blankenship MM, Ockner RK 1979 Validation of recording spectrophotometric method for measurements of membrane associated $\mathrm{Mg}$ and $\mathrm{Na}^{+}-\mathrm{K}^{+}$-ATPase activity. $\mathcal{J}$ Lab Clin Med 93:790-799

25. Lowry OH, Rosebrough NJ, Lewis Farr A, Randall RJ 1951 Protein measurement with the folin phenol reagent. J Biol Chem 193:265-275

26. Pershadsingh HA, McDonald TM 1980 A high affinity calcium-stimulated magnesium dependent adenosine triphosphatase in rat adipocyte plasma membranes. J Biol Chem 255:4048-4053

27. Vaughn WK, Neal RA, Anderson AJ 1976 Computer estimation of the parameters of the sigmoid kinetic model. Comput Biol Med 6:1-5

28. Feher JJ, Wasserman RH 1979 Evidence for a membrane-bound form of chick intestinal calcium binding protein. Biochem Biophys Acta 585:599-610

29. Shimura F, Wasserman KH 1984 Membrane associated with vitamin D induced calcium binding protein. Endocrinology 115:1964-1972

30. Rubinoff $M$, Nellans HN 1985 Active calcium sequestration by intestinal microsomes. J Biol Chem 260:7824-7828

31. Walters JRF, Weiser MM 1984 Characterization of the vitamin D-dependent $\mathrm{Ca}^{++}$binding sites in rat intestinal Golgi-enriched membrane fraction. Biochem J 218:347-354

32. Maclaughlin J, Weiser MM, Freedman RA 1980 Biphasic recovery of vitamin D-dependent $\mathrm{Ca}^{++}$uptake by rat intestinal Golgi membranes. Gastroenterology 78:325-332

33. Ghishan F, Arab N, Shibata H 1990 Intestinal phosphate transport in spontaneously hypertensive rats and genetically matched controls. Gastroenterology 99:106-112

34. Brushi G, Brushi ME, Caroppo M, Orlandini G, Spaggiari M, Cavatorta A 1985 Cytoplasmic free $\left[\mathrm{Ca}^{2+}\right]$ is increased in the platelets of spontaneously hypertensive rats and essential hypertensive patients. Clin Sci 68:179-184

35. Le Quan Sang KH, Devynick MA 1986 Increased platelet cytosolic free calcium concentration in essential hypertension. J Hyperten 4:567-574 